\title{
Table of international legal instruments
}

\section{African Charter on Human and}

Peoples' Rights .......44, 168-70, 172, $175-7,180-81,186,188$, 193-4, 198-201, 207

American Convention on Human Rights

Charter of Fundamental Rights of the European Union 45

Charter of the Arab League.... 177, 257

Charter of the Organization of

African Unity 177

Charter of the United Nations........ 11, 39-40, 43, 168, 170-72, 175-7, 180, $188,199,207,234,257,271$

Constitutive Act of the African Union $11,170,188$

Convention on the Elimination of All Forms of Discrimination Against Women $44,47,176-8$, 192, 199, 201

Convention on the Prevention and Punishment of the Crime of Genocide 199

Convention on the Rights of the Child 44, 176-8, 192, 200-201

Declaration on the Rights of Persons Belonging to National or Ethnic, Religious and Linguistic Minorities $69,88,271$

East-West Basic Treaty.

European Convention on Human Rights 45,127
International Convention on the Elimination of All forms of Racial Discrimination 199

International Covenant on Civil and Political Rights. $44,88,175,192$, 198-9, 207, 271

International Covenant on Economic, Social and Cultural Rights $44,88,175,192$, 198-9, 207, 271

Treaty Establishing a Constitution for Europe ..................................103

Treaty establishing CEN-SAD (The Community of Sahel-Saharan States).

Treaty establishing the European Community....

Treaty of Lisbon ................... 125, 127,

Treaty of the Economic Community of West African States 188

Treaty on European Union ........11, 130 Treaty on the Functioning of the European Union 11-12

Tripoli Agreement.... 11

Universal Declaration of Human Rights ........39-40, 43-4, 88, 168-70, 172, 175-7, 180-81, 184, 186, 188, 193-4, 198-9, 201, 207, 227, 234, 257,271

Vienna Convention of the Law on Treaties 137 